\title{
India and the ASEAN: Taking relations to a new level
}

\author{
Dr.Mahua Das
}

\begin{abstract}
A b s tra $\boldsymbol{c}$ t: Asean, or the Association of South-east Asian Nations comprising of 10 countries located in South East Asia and its relations with India assumes special interest in the wake of the recently concluded summit at Phnom Penh. While the combined force of these countries in the South East Asia region cannot be underestimated, it faces a main challenge ahead of it to keep itself from being absorbed by the giant economies in East Asia specially China. The economic crisis faced during the period 1997-98 had paved the way for India taking up a pivotal role in this region. While general relationship between India and the ASEAN has been strengthened over the years, a positive outcome has been witnessed in economic relations where Free Trade Agreements have led to new opportunities and returns. Economic partnership among the nations is taking the relations to a new level as the members felt in the recent summit in Cambodia.
\end{abstract}

One Vision, One Identity, One Community.... So says the motto of ASEAN. But is ASEAN effective in today's scenario, and more still is it relevant? What is India's role in this alliance? This is a study dedicated to understand the relations between India and ASEAN, especially with respect to economic aspects and in the light of the recently concluded summit at Phnom Penh..

What is ASEAN?

ASEAN is an acronym for The Association of Southeast Asian Nations comprising of 10 countries located in South East Asia, viz. Indonesia, Malaysia, Philippines, Singapore, Thailand, Brunei, Myanmar, Cambodia, Laos, and Vietnam. The combined force of these countries cannot be underestimated- the combined nominal GDP of ASEAN countries had grown to US \$1.8 trillion in 2010. In fact, it was a single entity; ASEAN would rank as the largest economy in the world.

Among its other achievements, ASEAN has managed to reduce tariff levels in the region. It also seeks to encourage the free flow in investment by opening up industries for investment and eliminating aspects that are detrimental to investment.

While it is accepted that ASEAN is indeed powerful, it is also generally acknowledged that the main challenge ahead of it is to keep itself from being absorbed by giant economies in East Asia, especially China. This is perhaps where India would come in the picture- by increasing its interaction with ASEAN countries. Traditional Role of India towards ASEAN Countries:

India's relationship with ASEAN countries has traditionally been warm and cordial. In fact, India had significant links with countries in South East Asia- relations that managed to influence both countries in terms of religious and cultural influence. For instance, Indian traders have been known to have travelled to Indonesia since the $1^{\text {st }}$ century. Buddhism and Hinduism were a major influence in the country. Ancient Malaysia too was said to be under the influence of Tamil traders who established settlements in the Bujung Valley in the ancient Kingdom of Kedaram that date back to $3^{\text {rd }}$ Century AD.

As the Indian Prime Minister, Mr. Manmohan Singh observed in his opening remarks at the $10^{\text {th }}$ IndiaASEAN Summit, India's relations with Cambodia 'rests on the foundation of historical links and ancient cultural ties'. India's relations with Singapore as well date back to the $5^{\text {th }}-15^{\text {th }}$ centuries when pre-colonial Singapore was a part of a cultural region known as Greater India. Even in modern times, India has maintained cordial relations with these countries; it has supported the Indonesian struggle for freedom, signed bilateral treaties with Burma, Philippines, and Indonesia.

Trade links with the South East Asian countries was also established at the height of Chola Dynasty, especially during the reign of Rajendra Chola I, who in fact is credited with naming the island of Singapore or Singapura- the land of lions in the $10^{\text {th }}$ Century AD.

However, these relations faded over time (but the Tamil community still maintained a strong presence in countries like Singapore, Indonesia, Malaysia, etc.) as India was unable to capitalize these relationships for its benefits. It was primarily because of India's growing closeness to USSR as ASEAN countries did not have a positive opinion on the Soviet Union.

However, with the fall of the USSR, India began to reorient its foreign policy priorities and initiated a series of steps that aimed to revive relations with South-East Asian countries.

India's Look East Policy: 
A discussion between India and the South East Asian countries is certainly impossible without an understanding of the Look East Policy. As earlier said, it wasn't until the disintegration of the USSR that India decided to reorganize its foreign policy with other countries. The Look East Policy was a carefully strategized policy masterminded by the then Prime Minister P.V. Narsimha Rao. It was taken forward by Mr. Atal Behari Vajpayee, the Prime Minister who succeeded him. He offered the open sky policy to ASEAN countries thereby ensuring that there was better connectivity between the capitals of the 10 ASEAN countries and the metro cities of India.

The economic crisis faced by ASEAN countries during the period 1997-98 was also an eye opener for these countries to look for markets beyond South East Asia. India, with its strategic location in South East Asia was a viable market. They also awoke to the fact that it was risky to rely only on the Chinese market. As for India, garnering support from ASEAN was another tactic for restraining Pakistan from getting international support. It is well known that Islam is a religion of common practice in many ASEAN countries and an enduring friendship with these countries is in a way ensuring that Pakistan is kept out of international relationships.

General Relationship between India and ASEAN Countries:

\section{Political Relations:}

There has been a general consensus among political analysts that the Look East policy was a success and also resulted in a reciprocal Look West policy on the part of these South East Asian countries towards India. Such reciprocation not only opened the doors of economic opportunity, but also helped to realign the regional order in Asia. In fact, the trade between India and countries in this region increased to almost $28.2 \%$. The Mekong Ganga Cooperation is perhaps one of the most momentous outcomes since the start of the IndoASEAN bilateral relationship.

\section{The Mekong Ganga Cooperation}

The project was first proposed by the Thai Foreign Minister, Dr. S. Pitsuwan. This project aims to bring about greater cooperation between ASEAN countries and India with respect to tourism, culture, education, transportation, etc. It also paved the way for the Asian Highway Project- a highway that links Singapore with New Delhi via Kuala Lumpur, Ho Chin Minh City, Phnom Penh, Bangkok, Vientiane, Chaing Mai, Yangon, Mandalay, Kalemyo, Tamu, Dhaka, and Calcutta.

\section{BIMSTEC}

BIMSTEC is an acronym for Bay of Bengal Initiative for Multi-Sectoral Technical and Economic Cooperation. It involves greater cooperation between member countries, viz. Bangladesh, India, Myanmar, Sri Lanka, Thailand, Bhutan, and Nepal in sectors including trade and investment, transport, energy, tourism, technology, fisheries, agriculture, etc.

\section{Education:}

There has also been increased cooperation in the field of education. For instance, India has organized English training language for CLMV countries. India has also set up several EDC's or Entrepreneurship Development Centre in several South East Asian cities including Vientiane, Phnom Penh, Hanoi and Yangon.

\section{Terrorism:}

Terrorism has been another area of common interest between South East Asian countries and India. While, the plague of terrorism hasn't fully penetrated in these countries, bomb blasts in Bali in 2005, and the 2009 bombing at the Ritz Carlton Hotel in Jakarta are proof enough that these corners of the world aren't 100\% safe. India shares its maritime borders with Indonesia and Thailand and a land border with Myanmar and hence adequate steps have been taken to ensure that the sea lanes are insulated. In fact, as a result of continued efforts from both ends, piracy on the high seas has drastically fallen in these areas.

\section{Renewable Energy:}

India is a major contributor in terms of renewal energy capacity. Renewable energy today contributes to more than $6 \%$ of electricity requirements in the country. In fact, this sector has seen a steady rise; from a mere $3900 \mathrm{mw}$ in 2002-2003, it has now come to $25,00 \mathrm{mw}$ in March 2012. There have been steady talks in this sector, the latest one being held on the $7^{\text {th }}$ of November 2012. The two day workshop inaugurated by the Minister of New and Renewable Energy, Dr. Farooq Abdullah discussed several issues including the framing of regulatory framework for the promotion of renewable energy, to form a large scale strategy for long term developmental projects, discuss models for financing renewable energy projects, identify institutions for establishing long term 
cooperation, and adopt a ministerial meeting that would decide on the framework for future interaction on renewable energy.

\section{Economic Relations:}

A positive outcome of the relations between the two countries is the Free Trade Agreement. In 2006, both India and ASEAN decided on more trade in sectors such as agriculture, textiles, auto components, electronics etc. The agreement was aptly called Trade in Goods (TiG). But Indian businesses were apprehensive that ASEAN countries were more robust in sectors such as electronics, auto components, textiles, etc. and that India would have to face negative consequences. Thus, a list of around 1,400 products was included in the list. These products accounted for more than $42 \%$ of imports to India from ASEAN and hence trade wouldn't be affected. Thus, today, even after huge scale of export and import, India's exports have remained untouched.

As for trade, India is a major exporter of oil meals, gems, jewelry, meat and meat products, cotton yarn, rice, drugs and pharmaceuticals, rubber, etc. In fact, it has remained a strong factor in the ties between the South East Asian countries and India. Its trade with these countries has increased steadfastly and even arisen sharply since 2002, especially with Singapore. Imports from Thailand have also grown. As for investment opportunities, countries like Malaysia, Singapore, and Thailand are all increasing their investment in India.

India and ASEAN have also agreed on an FTA in 2009 to trade in duty free goods. This FTA was the world's largest FDA ever, since the one between India and China. Thus, it was agreed by both parties that $95 \%$ of trade in goods shall be liberalized. Thus, goods with zero tariffs include refrigerator, fans, air conditioners etc.

The ASEAN-India summit held recently in Phnom Penh has been observed to take relations with the 10-member bloc to a new level. The move to launch negotiations for a Regional Comprehensive Economic Partnership among the ASEAN countries and its economic partners including India was a "giant step" towards creating an economic community in the region. At the summit, India and the ASEAN extended their free trade agreement on goods to cover services and investment. They expect trade of $\$ 100$ billion by 2015 and $\$ 200$ billion over 10 years. These targets seem achievable with diversification of trade ties in areas from farm goods to energy and IT. Increasing the infrastructural and digital connectivity, the expanded trade pact will give India's service sector new avenues for growth overseas while advancing the scope of the much needed FDI.

Impact of the Indo-ASEAN Relationship on the World:

While it has already been discussed that the Look East policy was a success, we have to also consider the impact of the relationship on other countries viz. China and the US. Indeed India's closer ties with ASEAN have resulted in greater bilateral trade, but it is nothing compared to China's existing trade relationship with ASEAN. In fact, India's trade accounts for only 55 billion USD, while that of China is a whopping 235 billion USD. Countries like Vietnam still prefer to trade with China even though they've been ruled for thousands of years by the Chinese. There have been apprehensions that China could be a possible barrier to the actualization of India's Look East Policy. This apparently came to light in the wake of a scheduled meet between Prime Minister, Mr. Manmohan Singh and the Chinese Premier, Mr. Wen Jiabao. Just days ahead before the ministers were scheduled for a visit, 'People's Daily',the state-run newspaper ran an article criticizing India, saying that its Look East policy was in fact to encircle China. It questioned India's intention of cozying up to Japan, especially in the wake of a face off over the East China Sea crisis. India's attempt to engage in friendly association with Vietnam, Philippines, and Singapore is also criticized as taking advantage of the South China Sea crisis (a dispute between these countries and China).

It is no secret that India's attempt to reorient the regional balance of power in the Asian region shall be welcomed by the US. That could be the only way to curb China's growing influence in the world and the South East Asia in particular. The US is trying to contain China's aspirations with strategic alliances with countries like Singapore, Philippines, Vietnam, South Korea, (all in strong alliances with the US), Japan, and Australia. Thailand and Myanmar too are being dragged into this super power alliance. No wonder, President Obama's recent visit to Rangoon sent strong signals to China. Although there has been no official reaction from China, it would indeed be uncomfortable. As of now, China has ties with Burma through investments in the form of a dual pipe line running from Sittwe to Yunnan.

In June 2012, Leon Panetta announced that the US plans to increase its naval presence in the Indian Ocean by almost $60 \%$. Coupled with India's growing ties with ASEAN, this should be a problem for China which has almost come to exert a bossy attitude towards South East Asian countries and staking claims in resource rich East and South China Seas.

\section{Bibliography}

[1]. Chietigi Bajpaee, published in $31^{\text {st }}$ October, 2007, "India Rediscovers East Asia", Published by Asia Times.

[2]. Ellen Frost, published on $20^{\text {th }}$ April, 2009, "India's role in East Asia, Lessons from cultural and historical linkages.

[3]. K.A. Nilkanta Shastri, published in 1949 "South Indian Influences in the Far East"

[4]. Sanjeev Nayar, "Historical Ties between India and Indonesia", Published in Esamskriti.

[5]. Sultan Sahin, $11^{\text {th }}$ October, 2003, "India's Look East Policy Pays Off”, published by Asia Times. 